\title{
STRATEGI BERTAHAN HIDUP PETANI SAWAH TADAH HUJAN UNTUK PEMENUHAN KEBUTUHAN DI DESA SIDODADI KECAMATAN WONGSOREJO KABUPATEN BANYUWANGI
}

\author{
Dewi Khoiriyawati Firdaus ${ }^{1}$, Sri Wahyuni ${ }^{1}$, Titin Kartini ${ }^{1}$ \\ ${ }^{1}$ Program Studi Pendidikan Ekonomi, Fakultas Keguruan dan Ilmu Pendidikan, Universitas Jember \\ e-mail: sriwahyunipe.fkip@unej.ac.id
}

\begin{abstract}
Abstrak
Penelitian ini merupakan penelitian deskriptif kualitatif dengan tujuan untuk mendeskripsikan strategi bertahan hidup petani sawah tadah hujan untuk pemenuhan kebutuhan di Desa Sidodadi Kecamatan Wongsorejo Kabupaten Banyuwangi. Penentuan lokasi penelitian menggunakan metode purposive area, sedangkan penentuan informan penelitian menggunakan metode purposive yaitu informan penelitian adalah tiga orang petani sawah tadah hujan yang mempunyai lahan sendiri tidak lebih dari 0.5 ha dan mempunyai tanggungan anak sekolah minimal SMA. Pengumpulan data menggunakan metode wawancara, observasi dan dokumen. Analisis data yang digunakan dalam penelitian ini adalah reduksi data, penyajian data, dan penarikan kesimpulan. Hasil penelitian menunjukkan bahwa stategi bertahan hidup untuk pemenuhan kebutuhan yang dilakukan oleh petani sawah tadah hujan diantaranya yaitu strategi aktif, strategi pasif, dan strategi jaringan. Strategi aktif yang dilakukan yaitu dengan melakukan pekerjaan sampingan dan memperbolehkan anggota keluarga bekerja. Strategi pasif yang dilakukan yaitu dengan menerapkan pola hidup hemat dan menyimpan sebagian hasil panen untuk dikonsumsi sendiri. Sedangkan strategi jaringan yang dilakukan yaitu dengan meminjam uang kepada kerabat atau tetangga ketika membutuhkan uang secara mendesak.
\end{abstract}

Kata kunci: Strategi Bertahan Hidup, Pemenuhan Kebutuhan

\section{PENDAHULUAN}

Sektor pertanian sangat berperan penting bagi penyerapan tenaga kerja di pedesaan, terutama bagi masyarakat yang berpendidikan rendah. Sehingga sebagian besar masyarakat di pedesaan bekerja di sektor pertanian. Salah satunya yaitu Desa Sidodadi di Kecamatan Wongsorejo Kabupaten Banyuwangi, mayoritas penduduk di desa tersebut menggantungkan hidup pada sektor pertanian, hal ini dikarenakan rendahnya tingkat pendidikan, lapangan pekerjaan yang sempit, serta adanya budaya bertani yang diturunkan dari generasi ke generasi.

Petani Desa Sidodadi sebagian besar merupakan petani sawah tadah hujan, yaitu seseorang yang bergerak dalam bidang pertanian yang mengelola lahan pertaniannya sangat mengandalkan curah hujan. Petani sawah tadah hujan di Desa Sidodadi memiliki luas sawah sekitar 2.500-5.000 $\mathrm{m}^{2}$ dapat menghasilkan jagung pada panen sekitar $7 \mathrm{kwintal}-3$ ton. Pendapatan $\mathrm{Rp}$ 2.000.000-Rp 8.000.000, sedangkan panen cabe penghasilannya tidak menentu karena hasil cabe yang diperoleh tergantung dengan hujan. Jika terjadi musim kemarau yang berkepanjangan maka panen cabe akan menurun. Untuk tanaman kacang pendapatan yang diterima petani dari panen kacang sekitar Rp 700.000-Rp 5.000.000. 
Pendapatan yang diperoleh tersebut merupakan pendapatan kotor yang diperoleh oleh petani sawah tadah hujan. jumlah pendapatan tersebut bisa saja menurun jika kualitas tanaman petani kurang baik atau harga komoditi pertanian mengalami penurunan. Dengan pendapatan yang diperoleh tidak menentu mereka harus memenuhi kebutuhan pokok keluarganya antara lain yaitu kebutuhan pangan, sandang, papan, pendidikan dan kesehatan.

Pendapatan petani sawah tadah hujan yang tergolong rendah tidak mampu untuk memenuhi semua kebutuhan keluarga mereka karena untuk memenuhi semua kebutuhan keluarga dibutuhkan biaya yang cukup besar. Sebagaimana yang diungkapkan salah satu petani sawah tadah hujan di Desa Sidodadi yang mengatakan "Pendapatan dari hasil tani tidak cukup jika untuk membiayai semua kebutuhan pokok karena baru bisa mengolah sawah satu tahun sekali nunggu musim hujan saja."(A, 50th). Penulis tertarik untuk melakukan penelitian terhadap petani sawah tadah hujan karena peneliti ingin mengetahui bagaimana seorang petani sawah tadah hujan masih biasa bertahan hidup dijaman yang serba mahal ini. Menurut White (dalam Baiquni, 2007:47) yang menyatakan bahwa strategi survival atau strategi bertahan hidup merupakan strategi petani yang memiliki lahan yang sempit dan miskin, kelompok ini mengolah sumber daya alam yang sangat terbatas atau terpaksa bekerja apa saja terutama sebagai buruh tani atau buruh industri pedesaan dengan imbalan yang rendah, hanya sekedar menyambung hidup.

Disisi lain pendapatan seorang petani sawah tadah hujan masih tergolong rendah dibandingkan kebutuhan mereka yang besar, bagaimana upaya yang dilakukan oleh petani sawah tadah hujan tersebut untuk mengatasi kekurangan biaya yang diperlukan oleh petani sawah tadah hujan untuk memenuhi kebutuhan pokok keluarga. Menurut Sumardi dan Evers (1985:2), bahwa kebutuhan dasar manusia yaitu kebutuhan yang sangat penting guna kelangsungan hidup manusia yang terdiri dari kebutuhan atau konsumsi individu (makan, perumahan, pakaian) maupun keperluan pelayanan sosial tertentu (air minum, sinitasi, pendidikan, kesehatan dan transportasi).

Berdasarkan latar belakang di atas peneliti tertarik untuk melakukan penelitian dengan judul "Strategi Bertahan Hidup Petani Sawah Tadah Hujan untuk Pemenuhan Kebutuhan di Desa Sidodadi Kecamatan Wongsorejo Kabupaten Banyuwangi”"

\section{METODE}

Metode penentuan lokasi atau tempat penelitian menggunakan metode purposive area yaitu Desa Sidodadi Kecamatan Wongsorejo Kabupaten Banyuwangi. Penentuan informan penelitian meggunakan purposive yaitu informan penelitian adalah tiga orang petanni sawah tadah hujan yang memiliki lahan sendiri tidak lebih dari 0.5 ha dan memiliki tanggungan anak sekolah minimal SMA. Metode pengumpulan data yang digunakan terdiri dari metode : wawancara, observasi, dan dokumen. Teknik pengolahan data dalam penelitian ini menggunakan reduksi data, penyajian data, dan penarikan kesimpulan.

\section{HASIL DAN PEMBAHASAN}

\section{A. HASIL}

\section{1) Strategi Bertahan Hidup}

\section{a. Strategi Aktif}

Pendapatan informan yang tergolong rendah dan tidak sebanding dengan biaya kebutuhan yang sangat tinggi sehingga dibutuhkan strategi untuk memenuhi 
kebutuhan keluarga agar tetap bisa bertahan hidup. Informan menerapkan strategi aktif untuk menambah pendapatan keluarga dengan melakukan pekerjaan sampingan. Untuk dapat memenuhi semua kebutuhan keluarga, informan pertama melakukan beberapa pekerjaan sampingan antara lain yaitu menjadi penjual bibit cabai. Hal ini terungkap dari pengakuan informan yang mengatakan: "pekerjaan sampingan saya menjual bibit cabai sama buruh tani. Buruhnya tapi tidak setiap hari mbak kalau ada yang mebutuhkan tenaga saja saya buruhnya" $\left(A S, 53^{\text {th }}\right)$.

Walaupun telah melakukan beberapa pekerjaan namun pendapatan yang diterima tidak cukup untuk memenuhi semua kebutuhan keluarga secara layak sehingga anggota keluarga lainnya yaitu istri informan harus bekerja untuk menambah penghasilan keluarga. Hal ini terungkap dari pernyataan istri informan yang mengatakan: "kalau saya jadi buruh tani mbak tetapi tidak setiap hari bekerja, kalau tidak ada yang membutuhkan tenaga saya bantu-bantu bapaknya di sawah" (SU, $39^{\text {th }}$ ). Peran anggota keluarga dalam menambah penghasilan keluarga juga dilakukan anak pertamanya sebagai mana yang diungkapkan anak informan sebagai berikut:

"kalau sepulang sekolah atau liburan biasanya saya jahit, upah yang saya terima dari menjahit per bajunya 35 ribu untuk menambah uang saku dan transportasi. Tapi tidak setiap hari menerima jahitan mbak karena saya juga masih sekolah" $\left(L A, 18^{\text {th }}\right)$.

Informan yang kedua yaitu bapak Kateni. Informan kedua menerapkan strategi aktif dengan melakukan pekerjaan sampingan sebagaimana yang diungkapkan informan sebagai berikut: "pekerjaan sampingan yang saya lakukan membuka warung nasi" $\left(K A, 65^{\text {th }}\right)$. Melakukan pekerjaan sampingan dengan membuka warung nasi biasanya dilakukan ketika sore hari. Warung buka sekitar jam 4 sore-2 pagi.

Informan selanjutnya yaitu bapak Poniman. Informan ketiga juga menerapkan strategi aktif dengan melakukan pekerjaan sampingan sebagaimana yang diungkapkan informan sebagai berikut:"pekerjaan sampingan saya sebagai buruh tani dan memelihara sapi orang dengan sistem gadu" $\left(P E, 41^{\text {th }}\right)$. Walaupun telah melakukan beberapa pekerjaan sampingan namun pendapatan yang diterima belum cukup untuk memenuhi kebutuhan semua kebutuhan keluarga sehingga istri subjek juga bekerja untuk menambah penghasilan keluarga. Hal tersebut terungkap dari pernyataan informan yang mengatakan: "istri saya juga bekerja membungkus kerupuk, 100 bungkus kerupuk dapat upah 5 ribu,sehari biasanya hanya dapat 200 bungkus dengan upah Rp 10.000" (PE, $\left.41^{\text {th }}\right)$.

\section{b. Strategi Pasif}

Strategi pasif dilakukan informan agar pendapatannya mampu untuk memenuhi kebutuhan keluarga. Strategi pasif yaitu strategi bertahan hidup dengan cara meminimalisir pengeluaran keluarga (hemat). Strategi hemat dapat dilihat dari cara keluarga meminimalisir pengeluaran untuk kebutuhan keluarga seperti kebutuhan pangan, sandang, papan, pendidikan dan kesehatan. Sikap hemat dalam pemenuhan kebutuhan keluarga seperti yang diungkapkan informan mengatakan: "dengan makan seadanya tapi ya tetap 3 kali sehari lauknya sederhana makan sama tempe dan tahu. Kalau daging paling pas punya rejeki lebih saja" $\left(A S, 52^{\text {th }}\right)$. Sikap hemat juga terlihat 
tindakan subjek yang tidak menjual semua hasil panen jagungnya. Hasil panen jagung yang mereka dapat juga digunakan untuk konsumsi sehari-hari. Karena mereka beranggapan bahwa jika mengkonsumsi nasi jagung akan tahan lapar lebih lama, sehingga bisa mengurangi pengeluaran.

Informan yang kedua yaitu bapak Kateni. Strategi pasif yang dilakukan yaitu dengan mengkonsumsi makanan yang sederhana dengan lauk seadanya dan tidak menjual semua hasil panen jagungnya untuk dikonsumsi sendiri, sebagaimana penyataan informan yang mengatakan: "hasil panen jagung tidak semuanya saya jual mbak, saya simpan untuk konsumsi. Makan nasi jagung juga bisa tahan lapar lebih lama mbak jadi bisa menghemat pengeluaran juga" (KA, $\left.65^{\text {th }}\right)$.Sikap hemat lainnya juga terlihat dari tindakan informan yang menyisihkan sebagian pendapatannya untuk ditabung. Hal tersebut terungkap dari pernyataan subjek yang mengatakan: "sebagian dari pendapatan yang saya peroleh saya tabung mbak tapi saya simpan sendiri. (KA, $65^{\text {th }}$ )

Informan yang ketiga yaitu bapak Poniman. Strategi pasif yang dilakukan yaitu dengan mengkonsumsi makanan sedanya dan tidak menjual hasil panen untuk konsumsi. Sifat hemat lainnya juga terlihat dari tindakan subjek yang menyisihkan pendapatannya untuk ditabung. Hal tersebut terungkap dari pernyataan informan yang mengatakan: "pendapatan saya sebagaian saya tabung mbak, tapi nabungnya saya dengan cara ikut arisan" (PE, $\left.41^{\text {th }}\right)$

\section{c. Strategi Jaringan}

Strategi jaringan merupakan strategi bertahan hidup yang dilakukan dengan cara meminta bantuan kepada kerabat, tetangga dan relasi lainnya baik secara formal maupun informal ketika dalam kesulitan. Pendapatan petani sawah tadah hujan tidak menentu dan kadang mengalami penurunan hasil panen membuat subjek harus memiliki strategi ketika sedang membutuhkan uang secara mendesak. Meminjam uang merupakan langkah yang dilakukan untuk mendapat uang secara cepat, informan biasanya meminjam uang kepada saudara dan tetangga terdekat. . informan biasanya meminjam uang kepada saudara dan tetangga terdekat. Hal tersebut diungkapkan informan yang mengatakan: "jika saya mengalami kesulitan keuangan saya hutang kepada saudara atau tetangga" $\left(A S, 52^{\text {th }}\right)$.

Informan yang kedua yaitu bapak Kateni. Strategi ini adalah strategi terakhir karena subjek sebisa mungkin akan tetap berusaha sendiri tanpa meminta bantuan orang lain ketika membutuhkan uang secara mendadak, maka subjek akan meminjam uang kepada kerabat atau tetangga terdekat. Sebagaimana pernyataan subjek yang mengatakan: "kalau saya membutuhkan uang secara mendadak saya pinjam ke saudara atau tetangga" $\left(\mathrm{KA}, 65^{\text {th }}\right)$

Informan yang ketiga yaitu bapak Poniman. Untuk memenuhi kebutuhan yang secara mendesak subjek menerapkan strategi jaringan yaitu dengan memanfaatkan jaringan sosial yang dimiliki untuk mendapat bantuan seperti meminjam uang ketika sedang membutuhkan uang secara mendadak.Sebagaimana pernyataan informan yang mengatakan: "kalau sedang membutuhkan uang secara mendadak dalam saya hutang ke saudara atau tetangga" (PE, $\left.41^{\text {th }}\right)$. 


\section{2) Pemenuhan Kebutuhan}

\section{a. Kebutuhan Pangan}

Bagi petani sawah tadah hujan kebutuhan pangan sangat penting untuk menunjang stamina dalam bekerja. Keluarga petani sawah tadah hujan mengkonsumsi makanan sehari sebanyak tiga kali, terkadang juga hanya mengkonsumsi makanan sebanyak 2 kali sehari. Makanan yang dikonsumsi petani sawah tadah hujan disesuaikan dengan pendapatan yang mereka peroleh, seperti sayur-sayuran, tahu, tempe, dan kerupuk. Mereka jarang sekali memenuhi kebutuhan pangannya dengan asupan buah-buahan, hanya sesekali saja ketika ada uang lebih, begitu juga dengan susu mereka jarang sekali meminum susu setiap harinya. Hal ini sesuai dengan pernyataan bapak Agus berikut ini: "untuk makan sehari-hari saya cuma pakek sayur mbak, lauknya ya paling tahu, tempe dan kerupuk. Kalau makan daging paling pas ada uang lebih saja mbak" ( $\left.A S, 52^{\text {th }}\right)$

Keterangan yang disampaikan informan diatas tidak jauh berbeda dengan yang disampaikan bapak Kateni dan bapak Poniman sebagai berikut ini:

"kalau makan sehari-hari saya mengkonsumsi makanan sederhana mbak. Biasanya sayur lauknya paling ya tahu atau tempe. Jarang-jarang mbak makan daging biar hemat" (KA, 65 $\left.{ }^{\text {th }}\right)$

"kalau saya makan sehari-hari ya dengan sayur-sayuran lauknya ya tahu atau tempe. Yang ganti-ganti tiap hari paling ya cuma sayurnya mbak kalau lauknya ya itu-itu saja mbak" (PE, $\left.41^{\text {th }}\right)$

Berdasarkan ungkapan informan menunjukkan bahwa mengkonsumsi daging untuk kebutuhan pangan seorang petani sawah tadah hujan itu sudah mewah, sehingga mereka hanya makan makanan yang sederhana dengan lauk seadanya.

\section{b. Kebutuhan Sandang}

Kebutuhan akan pakaian setiap harinya dibutuhkan oleh setiap orang untuk melindungi dirinya dari panas, dingin dan hujan. Sama halnya dengan petani sawah tadah hujan, mereka membutuhkan pakaian untuk melindungi tubuhnya. Untuk setiap harinya pakaian yang digunakan oleh petani sawah tadah hujan dengan pakaian yang sederhana mereka tidak mengikuti trend pakaian yang baru karena uang yang dimilikinya lebih baik digunakan memenuhi kebutuhan lainnya. Keluarga petani sawah tadah hujan tidak pernah menjadwalkan kapan mereka harus membeli pakaian. Biasanya mereka membeli pakaian ketika menjelang hari raya itupun mereka lebih mengutamakan pakaian anak-anaknya. Seperti halnya pernyataan dari bapak Agus sebagai berikut: "saya kalau membeli pakaian biasanya satu tahun sekali ketika hari raya saja itupun yang penting anaknya dulu mbak, kalau saya sama ibunya ngalah pas ada lebihnya ya beli mbak" ( $\left.A S, 52^{\text {th }}\right)$

Keterangan yang disampaikan informan diatas tidak jauh berbeda dengan yang disampaikan bapak Kateni dan bapak Poniman sebagai berikut ini:

"kalau pakaian untuk sehari-hari banyak mbak, tapi kalau untuk pembelian pakaian ya satu tahun sekali ketika hari raya saja” $\left(K A, 65^{\text {th }}\right)$ 
"Kalau pas ada rejeki lebih ya beli baju mbak, paling yang diutamakan anakanaknya dulu mbak. Saya sama ibunya beli bajunya menunggu kalau ada sisa uangnya saja mbak." (PE, $\left.41^{\text {th }}\right)$

Dari pernyataan subjek tersebut dapat diketahui jika kebutuhan pakaian bagi keluarga petani sawah tadah hujan tidak begitu penting dibandingkan dengan kebutuhan yang lainnya. Mereka lebih mengutamakan pakaian yang diperluakan oleh anak terlebih dahulu.

\section{c. Kebutuhan Papan}

Kondisi rumah yang dimiliki petani sawah tadah hujan dengan tembok dinding dan lantai keramik bagian depan saja namun bagian belakang masih beralaskan tanah. Tidak banyak juga perlengkapan yang ada di dalam rumahnya. Dalam membeli perlengkapan rumah para petani sawah tadah hujan membelinya terkadang dalam jangka waktu panjang. Karena mereka lebih memilih perlengkapan rumah yang bisa dipakai bertahun-tahun. Sehingga dalam mengalokasikan pendapatan petani sawah tadah hujan untuk kebutuhan papan tidak dapat diprediksikan, alasan tersebut karena kebutuhan papan yang dibutuhkan petani sawah tadah hujan bersifat tidak pasti contohnya seperti perbaikan rumah yang rusak karena untuk pemenuhan kebutuhan papan buruh tambak lebih mengutamakan pemeliharaan rumah. Hal tersebut diungkapkan oleh salah satu informan yaitu bapak Poniman yang mengatakan: "tidak ada biaya khusus untuk perawatan rumah mbak, sesuai kondisi saja. Kalau ada yang rusak baru diperbaiki ini saja mulai pertama bikin gak pernah diperbaiki mbak" (PE, $41^{\text {th }}$ ).

Keterangan yang disampaikan informan diatas tidak jauh berbeda dengan yang disampaikan oleh informan lain sebagai berikut ini:

"Kalau ada yang rusak saja baru diperbaiki mbak tidak ada biaya khusus untuk perawatannya." $\left(K A, 65^{\text {th }}\right)$

"Tidak ada biaya khusus untuk perawatan rumah, sesuai kondisi saja mbak kalau ada rusak ya baru diperbaiki." $\left(A S, 52^{\text {th }}\right)$

\section{d. Kebutuhan Pendidikan}

Kebutuhan pendidikan merupakan kebutuhan penting yang harus dipenuhi bagi setiap orang. Dalam kehidupan sudah tentu orang tua menginginkan pendidikan yang terbaik untuk anaknya. Rendahnya pendidikan petani sawah tadah hujan yang hanya lulusan SMP bahkan masih ada petani sawah tadah hujan yang belum tamat SD membuat mereka kesulitan dalam mencari pekerjaan. Sehingga mereka hanya bekerja sebagai petani dengan pendapatan yang tergolong rendah dan tidak menentu. Melihat kondisinya saat ini mereka menginginkan agar anaknya mempunyai masa depan yang lebih baik. Seperti halnya yang diungkapkan oleh bapak Agus yang mengatakan: "Alhamdulillah anak saya dua-duanya masih sekolah semua mbak. Meskipun biaya pendidikan sekarang mahal saya tetap ingin menyekolahkan anak paling tidak sampai SMA biar anak saya dapat pekerjaan yang lebih baik dari saya mbak" $\left(A S, 52^{\text {th }}\right)$. 
Keterangan yang disampaikan informan diatas tidak jauh berbeda dengan yang disampaikan oleh informan lain sebagai berikut ini:

"anak saya satu mbak sudah berkeluarga tapi saya membiayai cucu saya sekolah. Meskipun biaya pendidikan sekarang mahal saya ingin cucu saya tetap sekolah, supaya bisa dapat pekerjaan yang lebih baik dari saya." $\left(K A, 65^{\text {th }}\right)$

"Anaknya saya 2 mbak semuanya sudah sekolah. Anak yang pertama kelas 1 SMA yang kedua masih PAUD. Meskipun saya berkerja sebagai petani saya ingin menyekolahkan anak paling tidak sampai SMA supaya tidak bekerja seperti saya." (PE, $\left.41^{\text {th }}\right)$

Keterangan petani sawah tadah hujan di atas menunjukkan bahwa pendidikan anak merupakan salah satu hal yang dianggap menjadi sangat penting. Biaya pendidikan yang dikeluarkan para petani sawah tadah hujan tidak sedikit. Mereka harus menyisihkan pendapatannya untuk menunjang pendidikan anaknya. Dengan minimnya pendapatan yang diperoleh, petani sawah tadah hujan tetap mengusahakan pendidikan anaknya sampai jenjang SMA.

\section{e. Kebutuhan Kesehatan}

Kebutuhan kesehatan merupakan hal yang penting bagi setiap orang. Pemenuhan kebutuhan akan kesehatan juga harus dapat diperhatikan dari setiap anggota keluarga. Karena kesehatan merupakan syarat yang mutlak agar seseorang lancer dalam menjalani aktivitas sehari-hari. Sehingga diperlukan lingkungan yang sehat jasmani dan rohani. Bagi petani sawah tadah hujan kesehatan sangat penting untuk mendukung aktivitas sehari-hati. Keluarga petani sawah tadah hujan lebih mengutamakan pola makan yang teratur untuk menjaga kesehatan tubuh, daripada ada salah satu anggota keluarga yang sakit mereka harus mengeluarkan biaya lagi utuk berobat. Ketika ada salah satu anggota keluarga yang sakit mereka akan membeli obat di warung, meminum jamu atau mencari alternatif yang lainnya hal itu dirasa hemat daripada harus berobat ke dokter. Hal tersebut sesuai dengan pernyataan informan yang mengatakan: "kalau pas lagi sakit jarang ke dokter, paling beli obat diwarung kadang juga beli jamu atau pijat. Kalau masih belum sembuh ya periksa ke puskesmas" $\left(A S, 52^{\text {th }}\right)$

Keterangan yang disampaikan informan diatas tidak jauh berbeda dengan yang disampaikan oleh informan lain sebagai berikut ini:

"Tidak ada biaya khusus untuk kesehatan mbak. Kalau sakit paling ya beli obat ke warung atau pijat, kalau belum sembuh ya ke puskesmas mbak." $\left(K A, 65^{\text {th }}\right)$

"Tidak ada biaya khusus mbak buat pengobatan kalau merasa sakit cukup beli obat di warung mbak, tapi kalau terlalu capek ya pijat. Kalau beli obat di warung gak sembuh-sembuh baru periksa ke puskesmas." (PE,41 $\left.1^{\text {th }}\right)$

Berdasarkan pernyataan dari informan penelitian diatas menunjukkan bahwa kesehatan juga merupakan kebutuhan yang tidak kalah penting dengan kebutuhan yang lainnya, karena kesehatan itu yang paling utama dapat mendukung aktivitas 
sehari-hari setiap orang. Para petani sawah tadah hujan mengatasi masalah kesehatannya cenderung membeli obat di toko.

\section{B. PEMBAHASAN}

1) Strategi Bertahan Hidup

Berikut tabel strategi bertahan hidup yang dilakukan oleh informan penelitian:

Tabel 1 Strategi Bertahan Hidup Yang Dilakukan Informan

\begin{tabular}{|c|c|c|c|}
\hline \multirow{2}{*}{ Informan } & \multicolumn{3}{|c|}{ Strategi Bertahan Hidup } \\
\hline & Aktif & Pasif & Jaringan \\
\hline Agus & $\begin{array}{l}\text { Penjual bibit cabe dan } \\
\text { buruh tani } \\
\text { Istri bekerja sebagai } \\
\text { buruh tani } \\
\text { Anak bekerja sebagai } \\
\text { penjahit }\end{array}$ & $\begin{array}{l}\text { Menerapkan pola hidup } \\
\text { hemat } \\
\text { Menyimpan sebagian } \\
\text { hasil panen } \\
\text { Menyisihkan sedikit } \\
\text { pendapatan jika ada }\end{array}$ & $\begin{array}{l}\text { Meminjam uang kepada } \\
\text { tetangga atau saudara }\end{array}$ \\
\hline Kateni & Warung makan & $\begin{array}{l}\text { Menerapkan pola hidup } \\
\text { hemat } \\
\begin{array}{l}\text { Menyimpan sebagian } \\
\text { hasil panen }\end{array} \\
\begin{array}{l}\text { Menyisihkan sedikit } \\
\text { pendapatan }\end{array}\end{array}$ & $\begin{array}{l}\text { Meminjam uang kepada } \\
\text { tetangga }\end{array}$ \\
\hline Poniman & $\begin{array}{l}\text { Buruh tani dan } \\
\text { memelihara ternak } \\
\text { orang lain } \\
\text { Istri bekerja di pabrik } \\
\text { kerupuk }\end{array}$ & $\begin{array}{l}\text { Menerapakan pola hidup } \\
\text { hemat } \\
\text { Menyimpan sebagian } \\
\text { hasil panen } \\
\text { Menabung dengan cara } \\
\text { ikut arisan }\end{array}$ & $\begin{array}{l}\text { Meminjam uang kepada } \\
\text { tetangga atau saudara }\end{array}$ \\
\hline
\end{tabular}

Berdasarkan tabel diatas dapat diketahui bahwa strategi yang dilakukan keluarga informan yaitu strategi aktif, strategi pasif dan strategi jaringan. Strategi aktif yaitu dengan mengoptimalkan segala potensi dalam keluarga itu sendiri, strategi pasif yaitu strategi yang dilaukan dengan cara menerapkan pola hidup hemat, dan yang terakhir yaitu strategi jaringan yang merupakan cara lainnya dengan mengikuti berbagai jenis jaringan yang ada dilingkungannya. 
Strategi aktif merupakan strategi bertahan hidup yang dilakukan petani sawah tadah hujan dengan memaksimalkan sumber daya alam yang ada guna memperoleh pendapatan. Berdasarkan penelitian yang telah dilakukan, ditemukan bahwan petani sawah tadah hujan melakukan pekerjaan sampingan dengan menjadi penjual bibit cabai dan buruh tani. Fakta di atas sesuai dengan pendapat Kusnadi (2000:8) yang mengatakan bahwa strategi yang dilakukan masyarakat miskin agar dapat bertahan hidup adalah dengan melakukan bermacam pekerjaan untuk memperoleh penghasilan demi memenuhi kebutuhan keluarga, pekerjaan yang tersedia merendahkan martabat pun akan tetap diterima walaupun upahnya rendah. Usaha menambah pendapatan dengan melakukan pekerjaan sampingan ternyata hanya sedikit tambahan pendapatan dikarenakan pendapatan dari pekerjaan sampingan yang dilakukan oleh petani sawah tadah hujan tergolong kecil dan tidak menentu. Pendapatan petani sawah tadah hujan yang masil tergolong rendah membuat anggota keluarga seperti istri dan anak ikut bekerja untuk membantu menambah pendapatan keluarga. Menurut Scott (dalam Daulay, 2010:77) yang mengatakan strategi aktif adalah peningkatan asset yang dilakukan dengan cara melibatkan lebih banyak anggota keluarga yang ikut bekerja, memulai usaha kecilkecilan, menggadaikan barang, meminjam uang di bank atau linth darta. Pendapat Scott sesuai strategi bertahan hidup yang diterapkan oleh petani sawah tadah hujan di Desa Sidodadi.

Pendapat Kusnadi (2000:8) yang menyatakan strategi pasif adalah strategi dimana individu berusaha meminimalisir pengeluaran uang, strategi ini merupakan salah satu cara masyarakat miskin untuk bertahan hidup. Strategi pasif yang dilakukan petani sawah tadah hujan terlihat ketika memasuki musim kemarau. Karena pada musim kemarau petani sawah tadah hujan tidak bisa menanami lahannya dengan tanaman apapun, mereka hanya menunggu ketika musim hujan saja untuk bercocok tanam. Keluarga petani sawah tadah hujan telah mengusahakan hiduphemat untuk mencukupi kebutuhan sehari-hari, walaupun tidak mudah untuk membagi pendapatan hasil panennya yang pas-pasan dibarengi dengan kebutuhan saatini yang semuanya serba mahal.

Strategi jaringan adalah strategi bertahan hidup lyang dilaukan seseorang atau keluarga dengan cara meminta bantuan kepada kerabat atau tetangga ketika mereka membutuhkan kebutuhan secara mendadak. Hal ini sesuai dengan pendapat Suharto (2009:31) yang menyatakan strategi jaringan merupakan strategi bertahan hidup yang dilaukan dengan cara menjalin relasi, baik formal maupun dengan lingkungan sosialnya dengan lingkungan kelembagaan (misalnya meminjam uang kepada tetangga, mengutang di warung atau di toko, memanfaatkan program kemiskinan, meminjam uang kepada rentenir atau bank dan lain sebagainya). Meminjam uang merupakan salah satu langkah petani sawah tadah hujan untuk mendapatkan uang secara cepat. Hal itu dilakukan ketika mereka berada dalam keadaan yang sangat mendesak.

\section{2) Pemenuhan Kebutuhan}

Petani sawah tadah hujan bekerja mengolah lahannya semaksimal mungkin untuk memperoleh pendapatan, pendapatan tersebut mereka gunakan untuk memenuhi kebutuhan keluarganya. Pendapatan yang diperoleh petani sawah tadah hujan tidak sebanding dengan pengeluarannya untuk pemenuhan kebutuhan keluarga diantaranya kebutuhan pangan, sandang, papan, pendidikan dan kesehatan. Setiap manusia yang hidup di dunia memiliki kebutuhan dasar yang sama meskipun mereka memiliki perbedaan latar belakang sosial, 
ekonomi, budaya, agama dan pengetahuan. Setiap manusia yang akan bekerja memerlukan energi yang diperoleh dari makanan. Makanan yang dikonsumsi petani sawah tadah hujan disesuaikan dengan pendapatan yang mereka peroleh, seperti sayur-sayuran, tahu, tempe, dan kerupuk. Mereka jarang sekali memenuhi kebutuhan pangannya dengan asupan buah-buahan, hanya sesekali saja ketika ada uang lebih, begitu juga dengan susu mereka jarang sekali meminum susu setiap harinya. Sehingga dalam pemenuhan kebutuhan pangan, petani sawah tadah hujan masuk dalam kategori tidak memenuhi pola menu makanan 4 sehat 5 sempurna.

Pakaian yang dikenakan petani sawah tadah hujan dalam bekerja merupakan bakaian bekas lama yang sudah tidak dipakai lagi. Petani sawah tadah hujan tidak membutuhkan pakaian khusus untuk bekerja, asalkan muat dipakai dan bisa melindungi kulit dari sengatan matahari. Para petani sawah tadah hujan membeli pakaian setahun sekali pada saat mendekati hari raya idu fitri. Itupun yang lebih diutamakan pakaian anak-anaknya. Pemenuhan akan pakaian petani sawah tadah hujan dipengaruhi oleh tingkat pendapatan dan cenderung tidak mengikuti model baju yang terbaru. Dalam mengalokasikan pendapatan petani sawah tadah hujan untuk kebutuhan papan tidak dapat diprediksikan, alasan tersebut karena kebutuhan papan yang dibutuhkan petani sawah tadah hujan bersifat tidak pasti contohnya seperti perbaikan rumah yang rusak karena untuk pemenuhan kebutuhan papan petani sawah tadah hujan lebih mengutamakan pemeliharaan rumah dan tidak harus mengeluarkan atau mengalokasikan pendapatan banyak hanya saja beberapa yang harus dibayar setiap bualannya seperti biaya listrik. Biaya pendidikan yang dikeluarkan para petani sawah tadah hujan tidak sedikit. Mereka harus menyisihkan pendapatannya untuk menunjang pendidikan anaknya. Dengan minimnya pendapatan yang diperoleh, petani sawah tadah hujan tetap mengusahakan pendidikan anaknya sampai jenjang SMA. Rendahnya pendapatan yang diperoleh oleh petani sawah tadah hujan memaksa mereka menyekolahkan anaknya di sekolah yang biaya pendidikannya terjangkau dan mementingkan kualitas sekolahnya. Mereka beranggapan bahwa yang penting anak bisa sekolah entah dimanapun tempatnya.

Para petani sawah tadah hujan mengatasi masalah kesehatannya cenderung membeli obat di toko. Hal ini disebabkan karena pendapatan yang diperoleh petani sawah tadah hujan tergolong rendah. Biaya pengobatan yang mahal dan rendahnya pendapatan yang diperoleh petani sawah tadah hujan memaksa mereka meanfaatkan obat-obatan yang ada di warung sekitar rumahnya.

\section{PENUTUP}

Berdasarkan penelitian dan analisis data strategi bertahan hidup petani sawah tadah hujan untuk pemenuhan kebutuhan di Desa Sidodadi Kecamatan Wongsorejo Kabupaten Banyuwangi dapat disimpulkan bahwa petani sawah tadah hujan di Desa Sidodadi menerapkan tiga strategi untuk tetap bertahan hidup dalam memenuhi kebutuhan pokok keluarganya yaitu: strategi aktif, strategi pasif dan strategi jaringan.

Strategi aktif yang dilakukan petani sawah tadah hujan adalah dengan melakukan pekerjaan sampingan dan peran serta anggota keluarga. Pekerjaan sampingan yang dilakukan yaitu dengan menjadi buruh tani, pedagang, dan memelihara ternak orang lain, memperbolehkan istri dan anak dengan ikut bekerja demi membantu menambah pendapatan keluarga.

Strategi pasif yang dilakukan petani sawah tadah hujan yaitu dengan menerapkan pola hidup hemat sepeti untuk pangan makan dengan lauk seadanya, menyimpan sebagian hasil 
panen jagung untuk konsumsi sendiri, untuk kebutuhan sandang membeli pakaian ketika menjelang hari raya atau sedang mendapat untung banyak, untuk kesehatan berobat ke puskesmas atau dukun pijat, minum jamu tradisional atau membeli obat-obatan di warung dan menabung. Sedangkan Strategi jaringan yang dilakukan petani sawah tadah hujan pada umumnya meminjam uang kepada saudara atau tetangga jika membutuhkan uang secara mendadak.

Berdasarkan kesimpulan dari penelitian ini maka peneliti memberikan saran kepada petani sawah tadah hujan agar mempunyai usaha sendiri seperti berdagang atau yang lainnya, mengingat ketika musim kemarau sulitnya mencari pekerjaan. Petani sawah tadah hujan memanfaatkan lahan yang dimiliki untuk menanam tanaman yang membutuhkan sedikit air guna meningkatkan produktifitas, sehingga pendapatan yang diperoleh juga meningkat.

\section{DAFTAR PUSTAKA}

Baiquni, M. 2007. Strategi Penghidupan Di Masa Krisis. Yogyakarta: Ideas Media

Daulay, P. 2010. Survival Mekanism Victim Houshold of Lumpur Lapindo in Sidoarjo. Jurnal Organisasi Manajemen. UPBJJ-UT. Surabaya

Kusnadi. 2000. Nelayan Strategi Adaptasi Dan Jaringan Sosial. Bandung: Humaniora Utama Press

Suharto, E. 2009. Kemiskinan \& Perlindungan Sosial di Indonesia. Bandung: Alfabeta

Sumardi, M \& Evers, HD. 1985. Kemiskinan \& Kebutuhan Pokok. Jakarta: CV Rajawali Pers 